\title{
Impact of economic slowdown on migrant workers
}

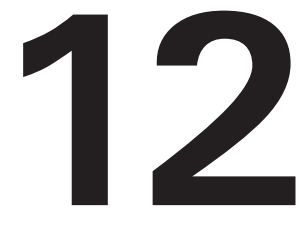

\section{Sherry Tao Kong, Xin Meng and Dandan Zhang}

\section{Introduction}

The recent global economic downturn has had a significant impact on employment in many countries and the full effect is yet to be felt, with the Organisation for Economic Cooperation and Development (OECD) expecting unemployment rates of about 10 per cent next year. It is noticeable that the economic downturn in China has been relatively mild in so far as economic growth is expected to be in the order of 6 or more per cent. Labour productivity growth, however, has been so significant in China in the past few decades that even a high output growth rate of this level is not sufficient to offset job losses, which are already apparent.

In China, the currently observed employment effect could be a product of three different events: first, the contractionary macroeconomic policies introduced by the government and central bank in 2007 aimed at slowing growth. It is interesting to note that the policy instruments adopted are likely to have the same impact on the economy as the current crisis. The second event was the introduction of the new Labour Contract Law at the beginning of 2008. This policy initiative sizeably increased the cost of unskilled labour and there is evidence that employers have responded by reducing labour inputs. The third event is the reduction in export orders due to the global financial crisis since the second half of 2008. These three events occurred sequentially and their impacts on employment have been borne most heavily by rural-urban migrants, as they form the major labour force for the export and low-cost labour-intensive industries in China. The close relationship between the timing of these events will make it difficult to estimate the contribution of each factor but it is nevertheless useful to bear in mind that the Chinese economic downturn from mid-2008 to early 2009 is the outcome of these combined effects. 
Generally speaking, the adverse effects of these three shocks impact most on the same set of people: rural-urban migrants. In 2008, about 130 million rural-urban migrants worked in cities and they accounted for one-third of the total urban labour force. They are heavily involved in export industries and building and construction, both of which have been particularly affected by the downturn. The disproportionate share of the adjustment that is being borne by migrant workers is an important policy issue. Not only should we be concerned about the uneven share of the cost of the economic downturn, the sheer number of migrant workers suggests that if the economic crisis is not handled properly, heavy job losses among migrants could affect economic and social stability.

In this chapter, we address two issues. First, we document the extent of employment loss and its geographic location and industry distribution. Second, we study which types of migrants are bearing most of the brunt of the downturn.

The Rural-Urban Migration in China and Indonesia (RUMiCI) project provides a unique set of data to help understand these issues. The project began in the second half of 2007. As a major part of the research, we surveyed 5000 migrant households in 15 cities. During the process of sampling, interviewing, tracking and re-interviewing this group of migrants, we have accumulated a considerable amount of data to provide a detailed record of what is happening.

The chapter is structured as follows. The next section provides background information on the economic policy environment during the period leading up to and during the economic downturn. Section three discusses the size of the impact on employment and section four examines the type of migrant worker separated from their jobs in 2008 because of the economic downturn. Conclusions are given in the last section.

\section{Background}

After double-digit growth in 2006 and, with the trade surplus and foreign reserve both hitting new highs, in 2007, rebalancing the economy moved onto the government's agenda. While in the first half of the year, the main concern was the rapid growth of asset prices (share and property prices), as the consumer price index (CPI) and producer price index (PPI) rallied during the second half of 2007, Chinese policymakers had to take measures to tame the beast of an overheating economy. Lending and deposit rates 
were lifted six times in 2007 and reserve requirements increased 10 times, reaching the highest levels for more than two decades. At the end of 2007, at the Central Economic Work Conference, the primary policy agenda for the next year remained 'two acts of prevention' - that is, to prevent the economy from overheating and to prevent the current structural inflation from turning into a broad-based one.

Against this macroeconomic background, the most significant reform to employment relations regulation in more than a decade was brewing. The Twenty-Eighth National People's Congress, held in June, formally approved the bill for the new Labour Contract Law, to take effect from 1 January 2008. For the first time, workers in domestic and foreignowned enterprises, including migrant workers, were entitled to collective consultation, severance payment, a minimum wage and other rights.

The significant implication of this law is, to some extent, reflected in the polarised drafting process since 2006 and the highly contentious debates preceding and following its formal adoption (Cooney et al. 2007). On the one hand, a rise in labour disputes and other social problems undermined social stability and called for the implementation of a national labour law. Furthermore, the Chinese Government has embarked on a development strategy that emphasises industrial upgrading and promotes social harmony. The long-term development agenda for the central government in turn translated into active promotion of innovative service industries, moving up the value scale while at the same time combating pollution at the local level. Proponents of the law argued that a set of regulations aimed at promoting workers' interests - particularly in forms of greater employment security and income protection - was urgently needed and would align with China's development agenda. On the other hand, the law inevitably increased labour costs, limited the flexibility of corporations to structure their employment arrangements and possibly 'over-regulates [the] employment relationship' (Zhao and Lim 2008).

On the ground, sharp reaction from employers had emerged long before the official promulgation of the law. While the drafting process was still under way, some factories were already gearing towards evading responsibility and potential additional costs under the new law. Wang et al. (2009) summarise two coping strategies used by employers. The first is 'creative compliance' (that is, evasion). Employers coerce many employees to resign their posts - thereby forfeiting important seniority claims - and then rehire them as new employees. For example, Huawei Technologies 
Company Limited, China's biggest maker of telecommunication network equipment, allegedly encouraged more than 7000 employees to take part in a 'voluntary resignation' scheme at the end of 2007 to avoid the obligation of giving employees who had served more than 10 years permanent positions ('ACFTU: Huawei agrees to suspend controversial employment scheme after union talks', People's Daily Online, 2007, $<$ http://english.peopledaily.com.cn/90001/90776/90882/6300313.html>).

The second strategy is reduction in employment, which has a stronger and more immediate implication for migrant workers. Many labourintensive manufacturers began to shut their factories and shift production to even lower-wage regions of China or South-East Asia. By one account, cited by Wang et al. (2009), 1000 footwear and accessory producers had reduced output or closed shop in Guangdong by early 2008. Some moved to the Chinese hinterland, while others relocated to Vietnam and Burma, where labour was cheaper and legally defenceless. Similarly, after the law took effect, already feeling the pinch of weakening export demand, business owners hurried to shed workers and rearrange work contracts so as to circumvent the new regulations ('Last call for Guangdong shoemakers', Asia Times Online, 2008, <http://www.atimes.com/atimes/ China_Business/JB05Cb01.html>).

China began 2008 with a growth rate of 13 per cent, a $\$ 29.3$ billion trade surplus and nearly $\$ 2$ trillion in foreign reserves. At the time, China's CPI had been increasing since 2002. By February 2008, it had soared by 8.7 per cent on a year-on-year basis (NBS 2009) - a 12-year high. In particular, prices of pork and cooking oil skyrocketed at the beginning of 2008, contributing to an increase of 14.3 per cent in overall food prices in 2008. In response, Chinese policymakers implemented a steady fiscal policy and tightened monetary policy to control the money supply and credit and stabilise expectations of inflation. This was the first time in 10 years that China had enforced a contractionary monetary policy. Aside from rising interest rates and increasing bank reserve requirements, the government also cut easy access to bank loans and reduced credit growth. Banking authorities strictly defined a 'second home' according to the property owned by the families of mortgage applicants rather than just the applicant. This was to control speculative home-buyers pushing up property prices to an artificially high level (Batson 2008). Quota controls on lending by commercial banks were also introduced. The export tax rebate was reduced and the renminbi was allowed to appreciate to balance China's trade surplus. 
While the government still feared the economy would overheat, coastal exporters and textile manufacturers were feeling the pinch from rising costs and weakening global demand. Meanwhile, property markets in some cities were softening. The employment impact of the external shock had taken shape. By mid-2008, rising costs and a slowdown in exports contributed to the closure of at least 67000 factories across China in the first half of the year, forcing labourers to scramble for other jobs or return home to the countryside (Wong 2008; 'China 2008: the global financial crisis', China Digital Times, 2008, $<$ http://chinadigitaltimes.net/2008/12/2008-financial-crisis-and-china/>). It was increasingly clear that overheating was no longer the main challenge, and policymakers gradually reduced the magnitude of the threat of inflation. The debate about de-coupling had become irrelevant and China quickly found itself having to refocus on sustaining economic growth amid a global slowdown. Accordingly, the 'two acts of prevention' policy gave way to 'one ensure and one control' - ensuring stable economic growth and controlling inflation. Policymakers halted the yuan's appreciation and boosted tax rebates to help exporters. The People's Bank of China (PBOC) cut interest rates in mid-September 2008, for the first time in six years, foreshadowing the stumble China might have to put up with.

The worldwide economic downturn has undoubtedly occupied centre stage since the last quarter of 2008. China's gross domestic product (GDP) recorded 6.8 per cent growth - unbelievably low by Chinese standards. In November 2008, China's exports declined by 2 per cent, which was the first drop in seven years. More than 600000 small and medium-sized companies were closed, putting millions of migrants out of work (Ramzy 2009).

To reboot the economy, a CNY4 trillion ( $\$ 586$ billion) stimulus package was unveiled in November. In the same month, the central bank also cut interest rates by 1.08 percentage points and lowered banks' reserve requirements. In addition, a host of policies was subsequently implemented to promote growth and employment through investment and consumption. These included policies such as the value-added tax (VAT) rebate for purchasing machinery and equipment, an increase in the export rebate, a loosening of controls on mortgage loans and the removal of quota controls on lending by commercial banks. Provided with the strong measures of credit expansion, the first quarter of 2009 has already observed a surge in renminbi-denominated loans. It takes time, however, for investment to be translated into output. During the first quarter of 2009, real GDP 
growth moderated to 6.1 per cent. In January, exports fell 17.5 per cent from a year ago - the biggest percentage decline since October 1998. The weakened export demand foreshadows the troubles ahead for millions of migrant workers who rely on factory jobs.

To gauge the employment impact on migrant workers, one has to take into account the external factors - such as plummeting export demand since late 2008 - and the dynamism of domestic policies, as well as the interaction of the two. In particular, in the past two years, China's macroeconomic policies have experienced a roller-coaster ride, from containing an overheating economy to injecting CNY4 trillion to provide a jump-start. Furthermore, the new Labour Contract Law has shaped the labour-intensive sector significantly-independently of the subsequent external shock. Taking into account the major events that have shocked the employment of migrant workers, a set of hypotheses can be derived to set the stage for disentangling the separate impacts of each event:

- regional differences (the Labour Contract Law should be applied across the board, but the export demand shock should affect coastal regions more than interior areas)

- time difference (the Labour Contract Law impacted from 2007 to mid2008, while this was compounded by the effects of the global recession after mid-2008)

- sectoral difference (the global downturn primarily affects construction and manufacturing).

\section{The size of the adverse employment effect}

\section{Existing estimates}

How badly did contractionary macroeconomic policies, the new Labour Contract Law and the global financial crisis affect the employment of migrants? Three survey-based estimates have recently revealed a very gloomy picture. One survey, carried out by the Chinese Ministry of Agriculture in January 2009, covered 150 counties in 15 provinces that were known to be major migration sending areas. Based on this survey, about 15.3 per cent of the 130 million migrant workers - 20 million - lost their jobs due to the global financial crisis. ${ }^{1}$

Another official survey was conducted by the National Bureau of Statistics (NBS) of China, covering 68000 rural households in 31 provinces, 
857 counties and 7100 villages between the end of 2008 and early 2009 . The estimates based on these data show that, in 2008, about 140 million rural migrants worked in cities. By the end of 2008, 50 per cent had returned to their home villages, of which 80 per cent went back to cities after the Chinese New Year, while the remaining 20 per cent decided to stay in their rural hometown. The total effect was therefore that about 10 per cent of the migrant labour force returned to their home village.

The third source of information is a series of small-scale surveys conducted by the Xilu Migrants Survey Group between November 2008 and January 2009. Of the 809 individuals surveyed, 89.5 per cent returned home for the Chinese New Year by 14 January 2008-12 days before Chinese New Year. Some 46 per cent of the returning migrants said that they were returning earlier than usual, of which 76 per cent indicated that it was due to workplace shutdowns, downsizing or they had been forced by their employers to take extended holidays. About 35 per cent of the total number of migrants therefore returned home earlier than usual because of the economic downturn. Of the 89.5 per cent of migrants who returned home before Chinese New Year, 69 per cent indicated that they would definitely be going back to cities after the New Year, 7.2 per cent suggested they would not return to cities, while the remaining 24 per cent were uncertain at the time of the survey.

All three studies seem to indicate a similar size for the adverse impact of the economic downturn. These studies are, however, based primarily on surveys conducted at the sending end and on migrant intensions to return to cities. What really happened has not been revealed in the existing literature. Did they go back to cities and, if so, were they able to find jobs? In this chapter, we use more objective information gathered from the sampling, interviewing, tracking and re-interviewing of a group of migrants in the RUMiCI survey to gauge the size of the adverse impact of the economic downturn on migrant employment.

\section{$\mathrm{RUMiCl}$ survey and tracking method}

The RUMiCI project is a research collaboration initiated by The Australian National University and Beijing Normal University. The project surveyed three groups of households: 5007 rural-urban migrants who worked in 15 designated cities $^{2}$ in 2008; 5000 urban households in the same cities; and 8000 rural households from 10 provinces or metropolitan areas where the 15 cities were located. ${ }^{3}$ While the urban and rural household surveys 
use the existing NBS household survey samples, no available sampling frame exists for rural-urban migrants. Previous migration surveys have normally used a household-based sampling methodology, whereby interviewers in selected urban neighbourhood communities randomly select migrants. The main concern about this sampling method is that only a small proportion of migrants in Chinese cities live within urban neighbourhood communities. A large proportion of them live either in factory dormitories, at the back of the restaurants or construction sites where they work or in surrounding rural suburbs. A sample drawn from urban residential communities might be quite unrepresentative of the migrant population. The RUMiCI research team employs a unique and innovative sampling strategy to address this concern.

Essentially, the survey uses a sampling frame that is based on information collected in a census of migrant workers at their workplaces. More specifically, we divided our sample cities into 500 metre by $500 \mathrm{~m}$ blocks and randomly selected blocks equal to about 12 per cent of the sample size for each city. Within each block, a census was conducted of all the workplaces within the selected blocks and the questions included the industry type, total number of workers and total number of migrant workers. The data obtained from this census of workplaces were then used as the sampling frame and a simple random-sampling method was used to select our sample of migrant individuals. Once we located the individual migrant, the interview was conducted with his/her household. ${ }^{4}$

From October to December 2007, the project team conducted a block census in the 15 cities. The sampling and surveying were conducted between March and June 2008 after migrants came back to cities from their annual home visit for Chinese New Year. We interviewed 5007 migrant households in the 15 cities. At the time of sampling in March-April 2008, we observed that a sizeable number of workplaces were already shut down, mainly in Dongguan, Shenzhen and Guangzhou. The survey company indicated to us that this was the result of the implementation of the contractionary macroeconomic policy and the new Labour Contract Law.

Because the survey is designed to be a five-year panel, a tracking strategy has been developed. An important feature of the migrant population is a high degree of geographic mobility. This makes tracking very difficult. At the time of the survey, we recorded individuals' work and home addresses and contact details in the cities as well as in their home 
village. In addition, we recorded phone numbers of three close relatives or friends of the interviewee in case they or their households moved. These are normal tracking strategies adopted by any panel survey. We realised that our sample population was different and their high degree of mobility suggested that these simple tracking designs might need to be enhanced. We therefore developed further tracking incentives. First, each year, we conduct three lottery activities for all our sample respondents. The prize ranges from CNY50-2000 in the first year and will increase each year. The lottery is designed to cover 1.5 per cent of individuals, but if an individual follows the survey for five years the probability of receiving a prize increases to 20 per cent. Only when an individual is successfully tracked can his/her name be entered in the lottery. This information is made available to the interviewees at the time of the interview. We hope this will give respondents an incentive to keep us informed of their whereabouts. Second, we send a present to interviewees' rural home every year before Chinese New Year, hoping to strengthen the link between the interviewees and the project team.

Five months after the first-wave survey (October 2008), we contacted all the respondents to confirm their current contact details so that a gift could be sent to them. At the same time, the first lottery results were revealed. Soon after, in December, and again in February 2009, another two rounds of tracking were conducted. ${ }^{5}$ Despite all these efforts, however, the attrition rate for the 2008 survey was very high, which was closely associated with the economic downturn. To compensate for the high attrition rate, a re-sampling based on 2007 census data was carried out before the 2009 survey. It is important to understand, however, the validity of the 2007 census frame after the economic downturn. We revisited 13 per cent of the census blocks (64 blocks) from the original total of 489 blocks surveyed in 2007 to examine whether the workplaces recorded in 2007 had changed their operating status. ${ }^{6}$ This small-scale recensus provided us with another set of information to examine whether the original workplace had shut down, changed to a new entity or had not changed. It does not, however, inform us of the degree of downsizing within existing workplaces. It therefore gives us a lower-bound estimation of the impact of the economic downturn. 


\section{Estimates of the adverse employment impact using RUMiCl data}

Our 2007 census data calculated the number of workplaces and rural migrant workers by city and industry (Table 12.1). Among our sample migrants, 67 per cent were employed in the service and wholesale-retail trade sectors, while 18 per cent worked in the manufacturing industry. The manufacturing industries were heavily concentrated in the coastal regions. In addition, more than 70 per cent of the migrants were employed in eight coast cities (Guangzhou, Dongguan, Shenzhen, Shanghai, Nanjing, Wuxi, Hangzhou and Ningbo). These data give us a starting point in describing the pre-economic downturn employment situation for rural-urban migrants in our sample cities, with which we can compare the post-economic downturn employment data.

Two data sources are used to gauge the post-economic downturn employment situation: the block re-census data and the sample tracking data.

We classify our block re-census workplaces into those that have been shut down and those that have not. We then use this information together with the 2007 census data to draw implications on the proportion of workplaces in each industry within our 2007 census blocks that have shut down, and further use the inverse-probability as a weight to generate an implied shutdown ratio for the city as a whole. In addition, using the 2007 census data for the number of migrants employed in each workplace, we calculate the implied employment impact of these shutdowns. We report the proportion of workplaces being shut down after the economic downturn by city and industry (Table 12.2). In all 15 cities, about 9 per cent of the total number of workplaces had been closed since NovemberDecember 2007. Among these cities, Wuhan and Dongguan have the highest proportion of closed workplaces and in both cities almost all industries have been adversely affected. For the 15 cities as a whole, construction, manufacturing and various types of agencies have the highest levels of shutdowns. 


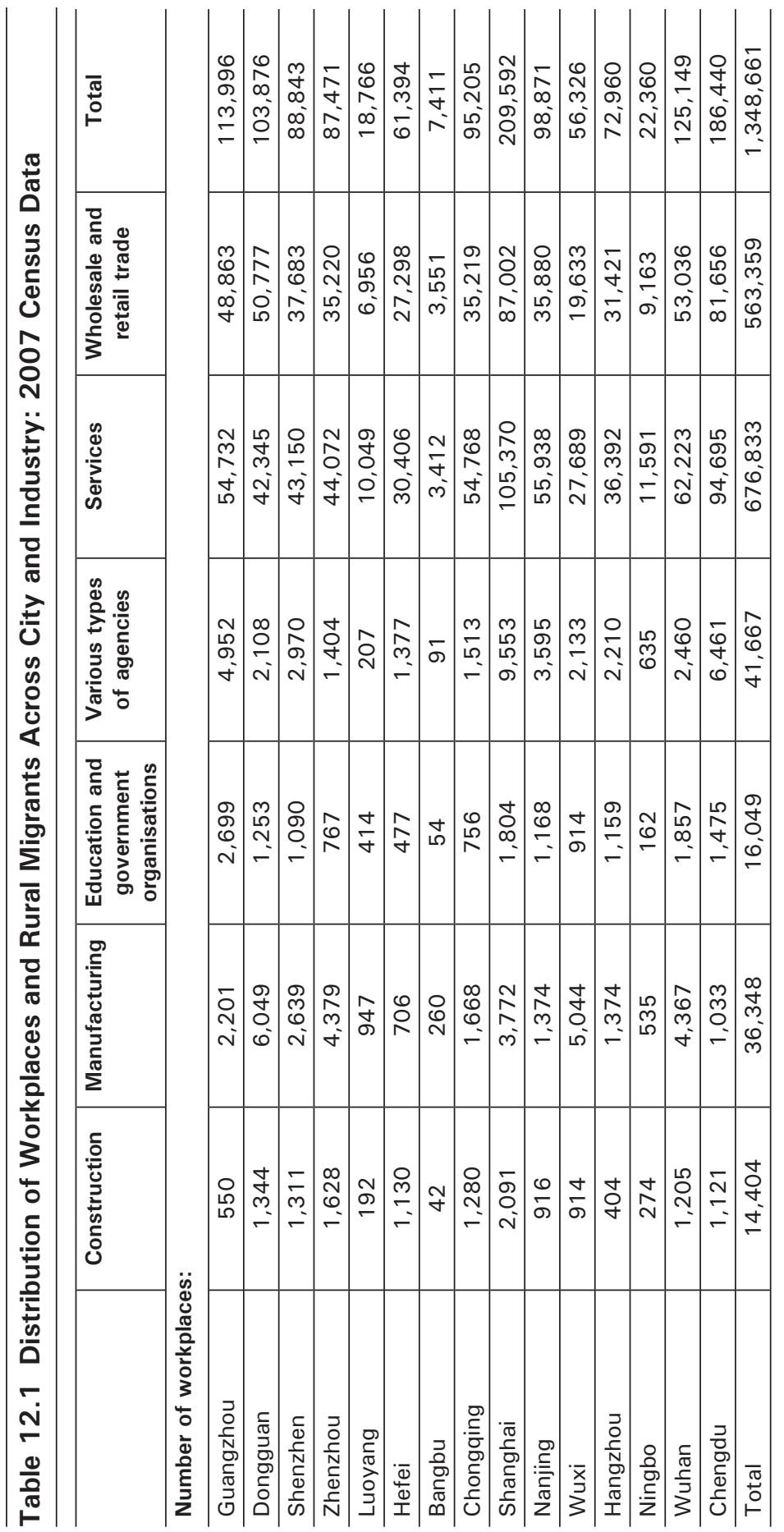




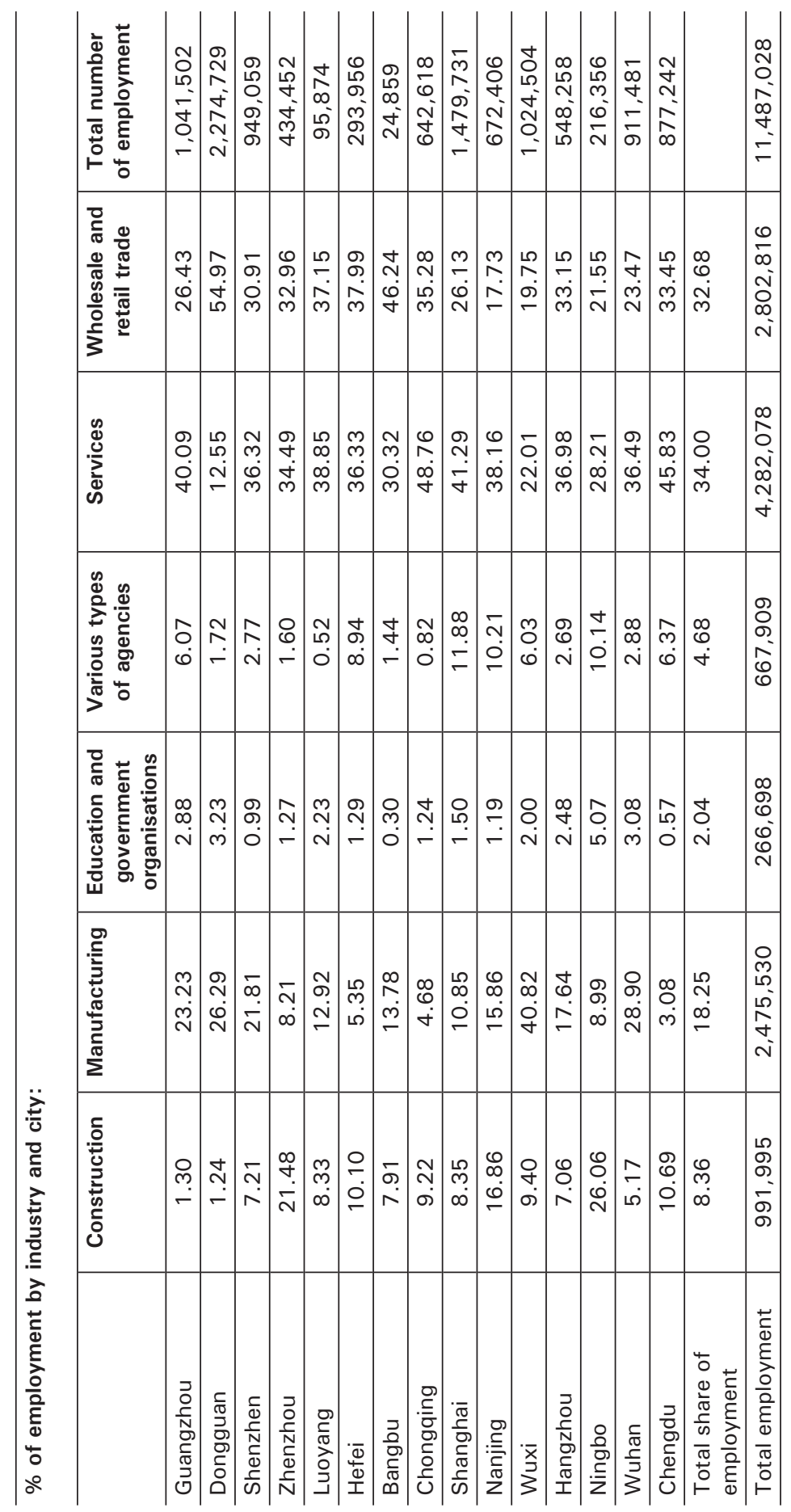




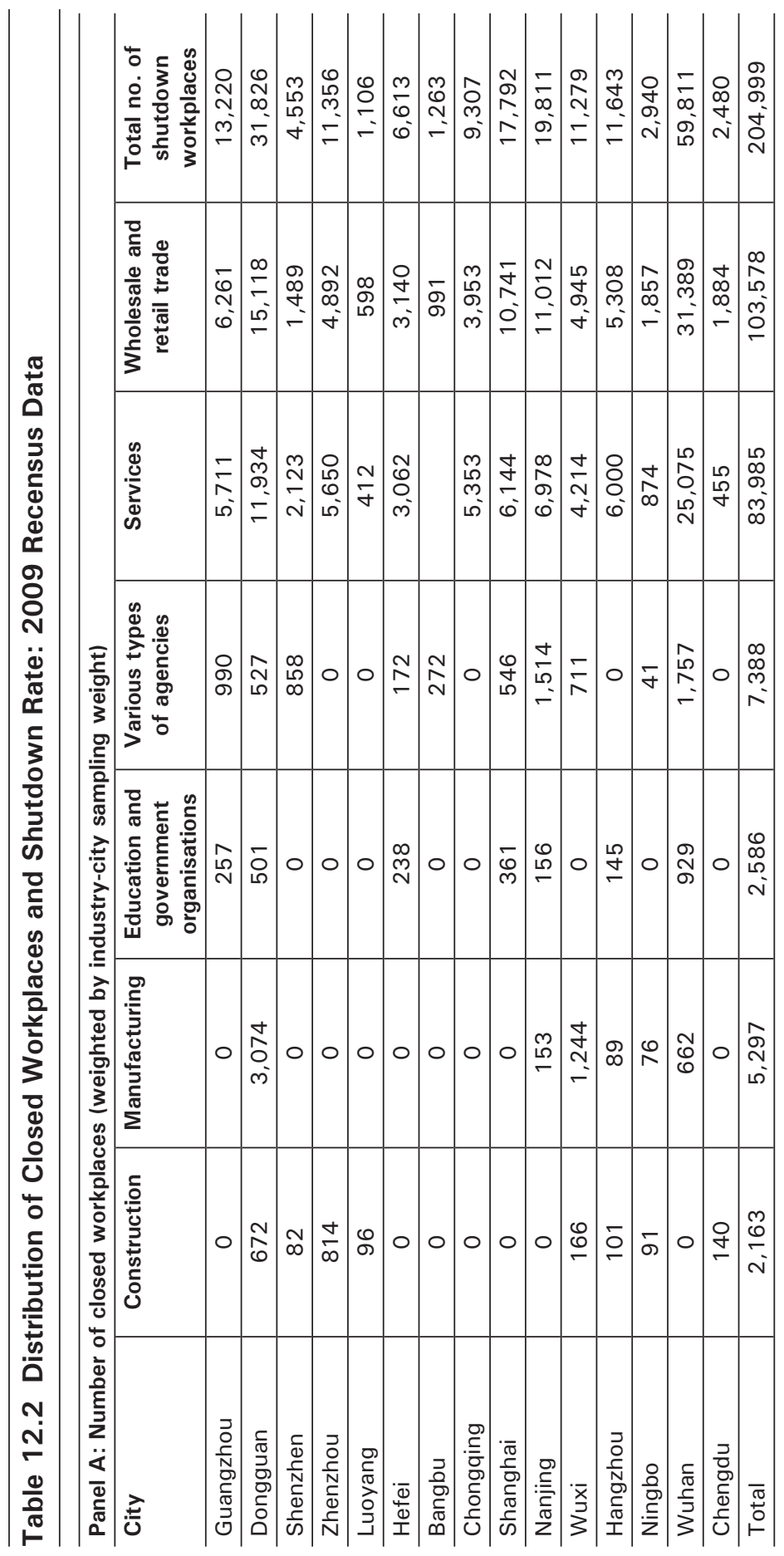




\begin{tabular}{|c|c|c|c|c|c|c|c|c|c|c|c|c|c|c|c|c|c|}
\hline & 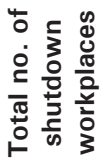 & 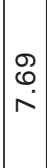 & \begin{tabular}{|l|}
0 \\
0 \\
$\dot{+}$ \\
N
\end{tabular} & $\hat{N}$ & 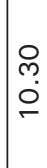 & $\begin{array}{l}m \\
0 \\
0 \\
\sim\end{array}$ & \begin{tabular}{|l|} 
\\
$\infty$ \\
0 \\
$\dot{0}$
\end{tabular} & $\begin{array}{l}1 \\
\dot{5}\end{array}$ & $\begin{array}{l}\hat{\varphi} \\
\dot{0}\end{array}$ & $\begin{array}{l}\dot{\sigma} \\
\dot{+}\end{array}$ & \begin{tabular}{l}
$\circ$ \\
$\infty$ \\
$\circ$ \\
\hdashline
\end{tabular} & $\begin{array}{l}\bar{\sigma} \\
\ddot{m} \\
\sigma\end{array}$ & 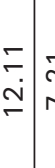 & $\begin{array}{c}\bar{N} \\
\end{array}$ & 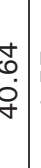 & 官 & $\frac{0}{\sigma}$ \\
\hline & 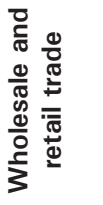 & $\stackrel{\bar{m}}{r}$ & $\begin{array}{l}\text { \& } \\
\stackrel{\mathrm{d}}{ }\end{array}$ & $\begin{array}{l}\stackrel{2}{N} \\
\sim\end{array}$ & 웜 & O̊ & $\begin{array}{l}\tilde{N} \\
0 \\
\infty\end{array}$ & $\begin{array}{l}\stackrel{0}{r} \\
\dot{\sigma}\end{array}$ & ס̄ & \begin{tabular}{|l|}
$\infty$ \\
\llcorner \\
\llcorner \\
0
\end{tabular} \mid & $\begin{array}{l}\stackrel{0}{\Gamma} \\
\check{\sigma}\end{array}$ & \begin{tabular}{l|l}
$\bar{\infty}$ & \\
$\infty$ & \\
&
\end{tabular} & \begin{tabular}{l|l}
$\hat{\sigma}$ & 0 \\
$\dot{n}$ & \\
& 0
\end{tabular} & 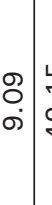 & مُ & 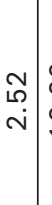 & $\begin{array}{l}\stackrel{ }{N} \\
\stackrel{2}{\sim}\end{array}$ \\
\hline & : & $\left|\begin{array}{l}\hat{0} \\
\infty\end{array}\right|$ & $\frac{\sqrt{n}}{\tilde{n}}$ & 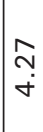 & $\begin{array}{l}0 \\
0 \\
0 \\
0\end{array}$ & $\mid \begin{array}{l}\mathscr{8} \\
0 \\
- \\
-\end{array}$ & $\mid \begin{array}{c}\overline{0} \\
\dot{0}\end{array}$ & $\begin{array}{l}\circ \\
0 \\
0\end{array}$ & 永 & $\begin{array}{l}\hat{N} \\
\dot{m}\end{array}$ & $\begin{array}{l}9 \\
\infty \\
\infty \\
\infty\end{array}$ & $\begin{array}{l}\hat{o} \\
\dot{\Sigma} \\
\bar{\sigma}\end{array}$ & 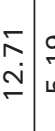 & \begin{tabular}{l|l}
$\mathscr{C}$ & \\
\multicolumn{1}{c}{} & \\
\end{tabular} & $\begin{array}{l}v \\
0 \\
\dot{j} \\
\text { m }\end{array}$ & $\begin{array}{l}\mathbb{M} \\
0 \\
0 \\
0\end{array}$ & $\begin{array}{l}\stackrel{\infty}{+} \\
\text { के }\end{array}$ \\
\hline & 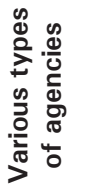 & 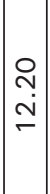 & $\begin{array}{l}\infty \\
0 \\
\stackrel{p}{N}\end{array}$ & $\begin{array}{l}\bar{\infty} \\
\\
\end{array}$ & $\begin{array}{l}0 \\
0 \\
0\end{array}$ & $\begin{array}{l}0 \\
0 \\
0\end{array}$ & $\mid \begin{array}{l}\hat{0} \\
\dot{0}\end{array}$ & 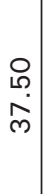 & ○े & Гా & $\begin{array}{l}\bar{\infty} \\
\stackrel{\dot{\omega}}{ } \\
\sim\end{array}$ & \begin{tabular}{l|l}
$\stackrel{L}{0}$ \\
$\stackrel{0}{\Sigma}$ \\
\end{tabular} & \begin{tabular}{l|l}
8 \\
\\
$\circ$
\end{tabular} & $\begin{array}{l}\text { வ } \\
\stackrel{\mathrm{N}}{ }\end{array}$ & 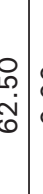 & $\begin{array}{l}8 \\
0 \\
0\end{array}$ & 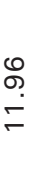 \\
\hline & 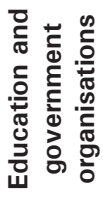 & 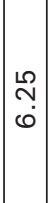 & 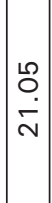 & $\begin{array}{l}8 \\
0 \\
0\end{array}$ & $\begin{array}{l}\circ \\
0 \\
0\end{array}$ & $\begin{array}{l}0 \\
0 \\
0\end{array}$ & 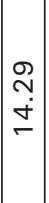 & $\begin{array}{l}\circ \\
\circ \\
\circ\end{array}$ & O̊ & 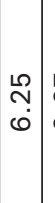 & $\begin{array}{l}\hat{\varphi} \\
\dot{0}\end{array}$ & \begin{tabular}{l|l}
8 & \\
$\circ$ & \\
$\circ$ &
\end{tabular} & $\begin{array}{l}\bullet \\
\llcorner \\
\llcorner \\
\llcorner\end{array}$ & $\begin{array}{l}8 \\
0 \\
0\end{array}$ & 年 & $\begin{array}{l}8 \\
0 \\
\circ\end{array}$ & $\frac{\dot{+}}{\dot{\sigma}}$ \\
\hline & 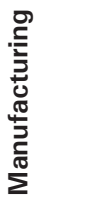 & $\begin{array}{l}0 \\
0 \\
0\end{array}$ & $\mid \begin{array}{l}m \\
\dot{g} \\
\dot{g}\end{array}$ & $\begin{array}{l}8 \\
0 \\
0\end{array}$ & $\begin{array}{l}8 \\
0 \\
0\end{array}$ & $\begin{array}{l}8 \\
0 \\
0\end{array}$ & $\begin{array}{l}0 \\
0 \\
0\end{array}$ & \begin{tabular}{l}
8 \\
\hdashline \\
$\circ$
\end{tabular} & Oִ & ○ & \begin{tabular}{l}
$\mathscr{8}$ \\
\hdashline \\
\end{tabular} & $\begin{array}{l}\text { Sू } \\
\stackrel{-}{N}\end{array}$ & $\frac{m}{\sim}$ & 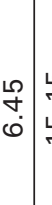 & $\stackrel{10}{\circ}$ & $\begin{array}{l}8 \\
0 \\
0\end{array}$ & 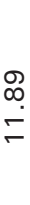 \\
\hline 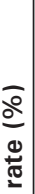 & 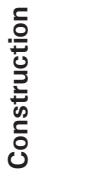 & $\begin{array}{l}0 \\
0 \\
0\end{array}$ & $\mid \begin{array}{l}0 \\
\tilde{m} \\
\dot{\rho} \\
\tilde{m}\end{array}$ & $\begin{array}{l}0 \\
0 \\
0\end{array}$ & \begin{tabular}{|l|} 
\\
\\
$\dot{6}$ \\
$\dot{g}$
\end{tabular} & $\mid \begin{array}{l}8 \\
8 \\
0 \\
\circ\end{array}$ & $\begin{array}{l}\circ \\
0 \\
0\end{array}$ & $\begin{array}{l}0 \\
0 \\
0\end{array}$ & $\begin{array}{l}0 \\
0 \\
0\end{array}$ & $\begin{array}{l}0 \\
0 \\
0\end{array}$ & $\begin{array}{l}\circ \\
0 \\
0\end{array}$ & \begin{tabular}{l|l}
$\infty$ & \\
$\stackrel{\infty}{\infty}$ & \\
- &
\end{tabular} & 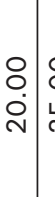 & \begin{tabular}{l|l}
8 \\
ọ \\
$\stackrel{1}{ }$
\end{tabular} & $\begin{array}{l}8 \\
0 \\
0\end{array}$ & $\begin{array}{l}8 \\
\stackrel{2}{ } \\
\stackrel{2}{*}\end{array}$ & $\begin{array}{l}\infty \\
\infty \\
\\
\end{array}$ \\
\hline $\begin{array}{l}\vec{z} \\
\omega \\
\ddot{\omega} \\
\bar{\Phi} \\
\frac{\bar{\Phi}}{\sigma} \\
\alpha\end{array}$ & $\frac{3}{0}$ & $\left|\begin{array}{c|}3 \\
0 \\
\frac{0}{N} \\
0 \\
\frac{1}{0} \\
0 \\
0 \\
0\end{array}\right|$ & 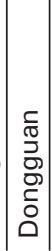 & $\left|\begin{array}{l}\frac{c}{d} \\
\frac{T}{N} \\
\frac{c}{d} \\
\frac{D}{\omega} \\
\text { d }\end{array}\right|$ & $\left|\begin{array}{l}\bar{\partial} \\
\frac{T}{N} \\
\frac{N}{d} \\
\frac{d}{N} \\
\mid\end{array}\right|$ & $\left|\begin{array}{l}0 \\
\stackrel{2}{0} \\
0 \\
0 \\
0 \\
3\end{array}\right|$ & 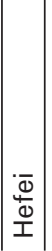 & 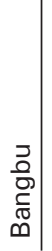 & 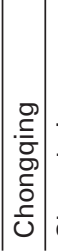 & $\begin{array}{l}\bar{\pi} \\
\frac{\pi}{0} \\
\frac{5}{\sigma} \\
\frac{\tau}{\sigma} \\
\frac{\tau}{\omega}\end{array}$ & 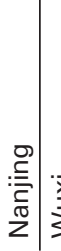 & $\sum_{3}^{\bar{x}}$ & 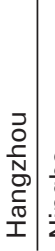 & 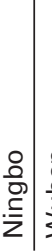 & 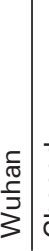 & 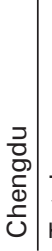 & $\bar{\Phi}$ \\
\hline
\end{tabular}


Matching the shutdown workplaces with the number of migrant workers hired by these workplaces in November-December 2007, we are able to examine the employment effect of the shutdown. We present the industry and city distribution of the impact of the shutdown on migrant employment for both calculations (Table 12.3). On average, about 13 per cent (or 1.4 million) of the migrants employed in the 15 surveyed cities were affected by the post-economic downturn shutdowns. Among the 15 cities, Dongguan has been hit the worst, with about 34 per cent of its migrant employment affected. The other cities badly affected are Wuxi and Ningbo, which has about 20 per cent of the migrant employment affected by shutdowns. If we believe that the global financial downturn affects mainly cities that are export oriented, we can rank our 15 cities according to their export concentration. Appendix 12.2 provides the proportion of export value to the city level GDP for each of our 15 cities for 2006 and ranks them accordingly. Among them, Shenzhen and Shanghai are ranked first and third. Surprisingly, their levels of migrant employment are among the lowest of the cities affected by the shutdowns, suggesting that perhaps there are factors other than the global financial crisis causing the current economic downturn.

Further, if we examine the industry distribution of the impact, we find that both the traded-goods industry (manufacturing) and the non-traded goods industry (wholesale and retail trade, for example) are affected. For example, in Wuhan, 28 per cent of migrant employment in the wholesaleretail trade sector is affected. From this point of view, it seems that domestic policies and the global financial crisis have had a sizeable impact. 


\begin{tabular}{|c|c|c|c|c|c|c|c|c|c|c|c|c|c|c|c|c|c|c|}
\hline & 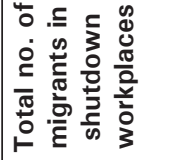 & 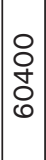 & $\begin{array}{l}\infty \\
0 \\
0 \\
0 \\
@ \\
\end{array}$ & $\frac{\bar{\sigma}}{\bar{\sigma}}$ & $\begin{array}{l}0 \\
\infty \\
\infty \\
\llcorner \\
\llcorner\end{array}$ & $\stackrel{N}{N}$ & 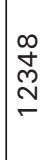 & $\begin{array}{l}\stackrel{m}{N} \\
\text { D }\end{array}$ & $\frac{\bar{\omega}}{\sim}$ & \begin{tabular}{l|l}
$L$ \\
$\infty$ \\
+ \\
$\infty$ \\
$\infty$
\end{tabular} & \begin{tabular}{l}
$\mathscr{0}$ \\
\multirow{1}{*}{} \\
$\stackrel{5}{0}$
\end{tabular} & 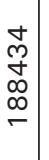 & 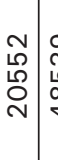 & & 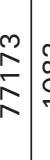 & 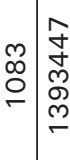 & & \\
\hline & 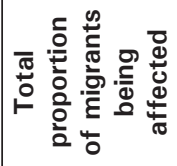 & $\mid \begin{array}{l}\infty \\
0 \\
\omega^{\circ}\end{array}$ & 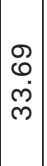 & $\begin{array}{l}\mathscr{0} \\
\stackrel{+}{\circ} \\
\dot{\sigma}\end{array}$ & $\begin{array}{l}\bar{\sigma} \\
\dot{m}\end{array}$ & $\begin{array}{l}\bar{m} \\
\stackrel{n}{\sim}\end{array}$ & $\frac{\sigma}{-}$ & $\begin{array}{l}\hat{L} \\
\dot{\nu} \\
\end{array}$ & 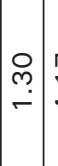 & $\begin{array}{l}\beth \\
\dot{\sigma}\end{array}$ & 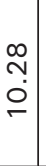 & 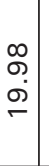 & 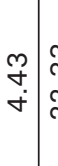 & \begin{tabular}{l|l}
$\stackrel{m}{m}$ & $g$ \\
$\underset{N}{N}$ & 0
\end{tabular} & 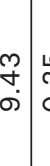 & 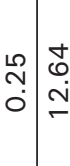 & 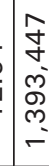 & \begin{tabular}{l}
$\qquad 0$ \\
\multirow{g}{\sigma}{} \\
6 \\
6
\end{tabular} \\
\hline ঐ̊ & 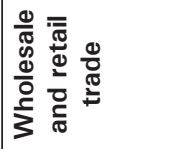 & $\begin{array}{l}\stackrel{1}{N} \\
\infty \\
\infty\end{array}$ & 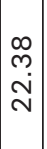 & $\begin{array}{l}\stackrel{L}{\sim} \\
\dot{+}\end{array}$ & $\begin{array}{l}\stackrel{m}{N} \\
\infty\end{array}$ & 足 & గִ & $\begin{array}{l}\infty \\
\hat{\infty} \\
\infty\end{array}$ & 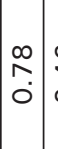 & $\begin{array}{c}0 \\
\dot{0} \\
\dot{\sim} \\
\text {. }\end{array}$ & $\begin{array}{l}\bar{\infty} \\
\dot{\sigma} \\
\bar{\sigma}\end{array}$ & $\begin{array}{l}\text { Oे } \\
\dot{+}\end{array}$ & ه্ & 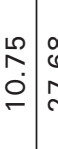 & 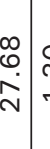 & 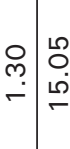 & 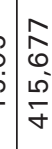 & \begin{tabular}{l}
0 \\
Oे \\
\multirow{+}{*}{}
\end{tabular} \\
\hline 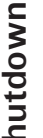 & 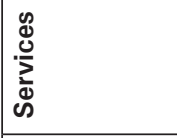 & $\frac{\infty}{\leftarrow}$ & \begin{tabular}{|l|} 
\\
0 \\
$\dot{j}$ \\
\end{tabular} & $\begin{array}{l}\hat{n} \\
\grave{N}\end{array}$ & $\begin{array}{l}0 \\
\llcorner \\
\dot{\rho} \\
\dot{m}\end{array}$ & $\begin{array}{l}N \\
\infty \\
0 \\
0\end{array}$ & $\begin{array}{l}\tilde{N} \\
\tilde{m} \\
\tilde{m}\end{array}$ & $\begin{array}{l}\text { O } \\
0 \\
0\end{array}$ & $\stackrel{m}{\stackrel{n}{r}}$ & \begin{tabular}{c|c}
$\mathbf{N}$ & \\
$i$ & \\
$\sim$ & 0
\end{tabular} & $\begin{array}{l}\dot{\sigma} \\
\dot{m}\end{array}$ & $\begin{array}{l}\stackrel{N}{+} \\
\dot{m}\end{array}$ & \begin{tabular}{l|l}
$\stackrel{2}{R}$ & 8 \\
$\infty$ & 8
\end{tabular} & \begin{tabular}{c|c}
$m$ & \multicolumn{1}{c}{} \\
$\dot{C}$ & \multicolumn{1}{c}{} \\
$\dot{m}$ &
\end{tabular} & $\stackrel{\square}{\sim}$ & 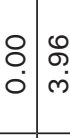 & 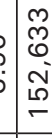 & 趈 \\
\hline 으 & 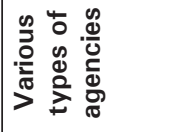 & $\begin{array}{l}\bar{\omega} \\
\infty \\
\infty \\
\sim\end{array}$ & 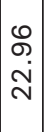 & $\begin{array}{l}\stackrel{L}{\circ} \\
\stackrel{0}{\circ}\end{array}$ & $\begin{array}{l}0 \\
\circ \\
0\end{array}$ & O̊ & ○ & $\begin{array}{l}\text { O } \\
0 \\
0\end{array}$ & $\begin{array}{l}0 \\
0 \\
0\end{array}$ & $\begin{array}{c}\stackrel{m}{\infty} \\
\stackrel{\infty}{\infty}\end{array}$ & 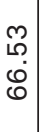 & 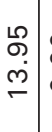 & \begin{tabular}{ll}
$\circ$ \\
\hdashline \\
\hdashline
\end{tabular} & 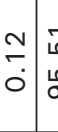 & 号 & 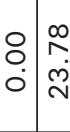 & مِ & 응 \\
\hline 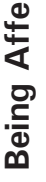 & 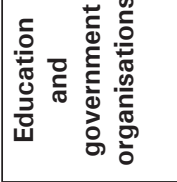 & $\begin{array}{l}m \\
+ \\
0 \\
0\end{array}$ & $\begin{array}{l}0 \\
0 \\
0\end{array}$ & $\begin{array}{l}\text { ○ } \\
\text { O. }\end{array}$ & $\begin{array}{l}8 \\
0 \\
0\end{array}$ & O̊ & $\begin{array}{l}1 \\
0 \\
\dot{\theta} \\
0\end{array}$ & $\begin{array}{l}8 \\
0 \\
0\end{array}$ & $\begin{array}{l}0 \\
0 \\
0\end{array}$ & \begin{tabular}{l|l}
$\infty$ & \\
$\dot{m}$ & \\
$\sim$ &
\end{tabular} & $\begin{array}{l}-\dot{0} \\
\end{array}$ & ○̊ & $\stackrel{2}{\circ} \stackrel{1}{-}$ & \begin{tabular}{l|l} 
& \multicolumn{1}{c}{} \\
& \\
\end{tabular} & $\begin{array}{l}0 \\
\stackrel{\circ}{-} \\
-\end{array}$ & 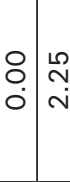 & 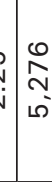 & $\stackrel{\bullet}{N}$ \\
\hline 竞 & 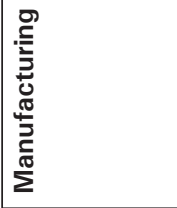 & $\begin{array}{l}\circ \\
0 \\
0\end{array}$ & $\mid \begin{array}{l}\infty \\
\infty \\
0 \\
0\end{array}$ & $\begin{array}{l}\text { 우 } \\
\text { O. }\end{array}$ & $\begin{array}{l}\circ \\
\circ \\
0\end{array}$ & ○ & ○ & $\begin{array}{l}\circ \\
0 \\
0\end{array}$ & $\begin{array}{l}\circ \\
\circ \\
0\end{array}$ & ○् & $\begin{array}{l}\circ \\
\circ \\
\circ\end{array}$ & $\begin{array}{l}\text { Oे } \\
\text { ते }\end{array}$ & $\begin{array}{l}\check{\dot{y}} \\
\dot{m}\end{array}$ & \begin{tabular}{l|l}
$\circ$ \\
\hdashline \\
\hdashline
\end{tabular} & \begin{tabular}{l|l}
$\stackrel{0}{c}$ & \\
$\dot{v}$ &
\end{tabular} & 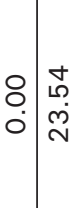 & in & $\begin{array}{l}\mathcal{N} \\
\text { กิ } \\
\text { ஸै }\end{array}$ \\
\hline$\frac{\frac{5}{0}}{\frac{5}{2}}$ & $\begin{array}{l}5 \\
.0 \\
0 \\
0 \\
0 \\
0 \\
0 \\
0 \\
0 \\
0\end{array}$ & $\begin{array}{l}0 \\
0 \\
0\end{array}$ & $\frac{1}{-0}$ & $\begin{array}{l}\stackrel{+}{+} \\
\stackrel{0}{0}\end{array}$ & $\begin{array}{l}0 \\
\dot{\sim} \\
\dot{N}\end{array}$ & 俩 & $\begin{array}{l}\circ \\
0 \\
0\end{array}$ & $\begin{array}{l}\text { O } \\
0 \\
0\end{array}$ & $\begin{array}{l}0 \\
0 \\
0\end{array}$ & ০০ & $\begin{array}{l}\text { ○. } \\
\dot{0}\end{array}$ & $\begin{array}{l}0 \\
\infty \\
\dot{0} \\
\stackrel{N}{N}\end{array}$ & \begin{tabular}{l}
8 \\
\hdashline \\
0
\end{tabular} & \begin{tabular}{l|l}
\multirow{2}{*}{} & \\
$\stackrel{0}{*}$ & $c$
\end{tabular} & $\begin{array}{l}8 \\
\text { ¿ } \\
\circ\end{array}$ & 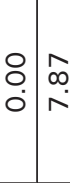 & $\begin{array}{c}\vdots \\
0 \\
0\end{array}$ & $\underset{⿱}{N}$ \\
\hline 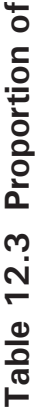 & & $\left|\begin{array}{c|}0 \\
0 \\
N \\
0 \\
0 \\
\frac{T}{0} \\
0 \\
0\end{array}\right|$ & 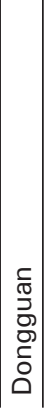 & $\begin{array}{l}\frac{\bar{d}}{\frac{N}{N}} \\
\frac{}{\Phi} \\
\frac{\stackrel{c}{\omega}}{\omega}\end{array}$ & $\left|\begin{array}{c}0 \\
\frac{0}{N} \\
\frac{1}{d} \\
\frac{T}{N} \\
\mid\end{array}\right|$ & 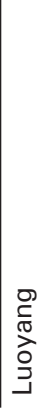 & $\begin{array}{l}\bar{\Phi} \\
\frac{\bar{\omega}}{\omega} \\
\bar{I}\end{array}$ & 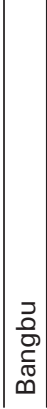 & 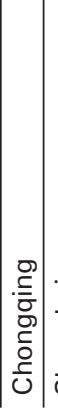 & $\begin{array}{l}\bar{\pi} \\
\frac{\pi}{0} \\
\frac{0}{c} \\
\frac{0}{\pi} \\
\frac{c}{\omega}\end{array}$ & 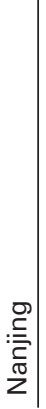 & $\sum_{3}^{\bar{x}}$ & 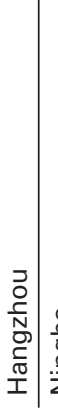 & 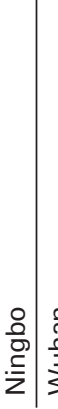 & 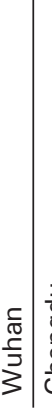 & \begin{tabular}{l|l}
$\frac{2}{0}$ & \\
0 & \\
$\frac{C}{0}$ & $\bar{\pi}$ \\
$\frac{\pi}{U}$ & 0 \\
0 & 1
\end{tabular} & 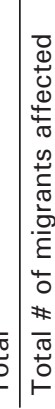 & 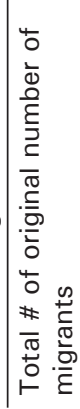 \\
\hline
\end{tabular}


Note that the shutdown effect is a lower-bound estimate of the extent of the total economic downturn effect on employment. From our re-census data, we are unable to examine the size of the downsizing within the existing workplaces. Our tracking data for the 5007 migrant households surveyed in 2008 could shed some light on this; however, using tracking data to infer the economic downturn effect on employment is quite tricky, as in a normal environment one expects a certain attrition rate. The literature does not provide a benchmark on the issue of what is a normal rate of attrition for an average population in a normal economic environment. Nevertheless, the Household Income and Labour Dynamics in Australia (HILDA) survey and the British Household Panel Survey (BHPS) could serve as such benchmarks. From the first to the second wave, HILDA has an attrition rate of about 13.2 per cent, while the rate for the BHPS is 12.4 per cent (Watson and Wooden 2004). We can therefore regard the 12-13 per cent attrition rate for HILDA and BHPS as a benchmark for an average population in a normal economic environment.

Our sample population, however, has much higher mobility and hence the attrition rate for the average population represented in HILDA and BHPS might not be a suitable benchmark for our purposes. In an industrialised country, the population regarded as highly mobile is the youth group - in particular, young men (for example, Olsen 2005). The attrition rate from wave one to wave two for the group aged twenty to twenty-four in the HILDA survey is 23.4 per cent (Watson and Wooden 2004).

The migrant population represented in our sample, although older with an average age of twenty-eight years, in fact faces a very different institutional environment to that facing youth in industrial countries. Because of the restrictions on accessing formal-sector jobs, social services and a social safety net in cities, migrants have very insecure jobs and, when they are fired, they have no safety net to rely on (Meng 2000; Meng and Manning 2010). They therefore tend to move around much more than an average population or even average youth. Using the data for the year since first migration and the number of cities worked in since first migration, we are able to calculate the average time migrants stay in one city. Among our 2008 sample of the 5007 migrant household heads, the median number of years they stayed for work purposes in one city was three (Figure 12.1). The average annual mobility therefore should be about 33 per cent without the economic downturn. Based on this information, we expect that the normal attrition rate for our sample between the first and second wave in a normal situation without an economic downturn should be about 30 per cent. 
Figure 12.1 Kernel density estimate

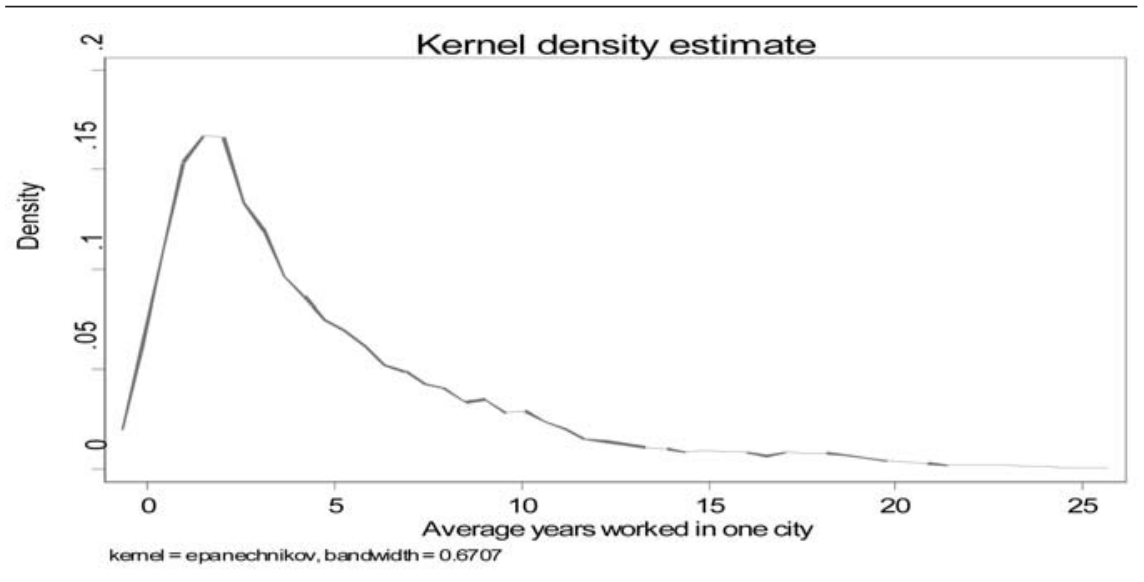

As discussed earlier, in October 2008, December 2009 and February 2009, we tracked our 5007 migrant households three times. Each time, our targeted tracking population was the 5007 original households surveyed. The attrition rate for each of these trackings is reported (Table 12.4). The attrition rate for the first tracking in October 2008 is 34.2 per centalready exceeding our expectation for a normal economic environment. Two months later, the second tracking resulted in a 39.4 per cent attrition rate with respect to the original 5007 sample households, or an additional 5.2 percentage point loss of our sample. Relative to the 3296 households being tracked in October 2008, the second attrition rate was 16.7 per cent. Finally, just before we embarked on the second-wave survey, the third tracking recorded an attrition rate of 48.8 per cent with respect to the original sample (an additional 14.6 percentage points relative to the first tracking), or 24.9 per cent with respect to the second tracked sample of 3035 households. This final tracking gives us an attrition rate that is 18.8 percentage points higher than our expected attrition for a normal economic environment. This could serve as an upper-bound estimation of the employment effects of the economic downturn. 
Table 12.4 Attrition rates for the three trackings

\begin{tabular}{l|c|c|c}
\hline & $\begin{array}{c}\text { First } \\
\text { (October) }\end{array}$ & $\begin{array}{c}\text { Second } \\
\text { (December) }\end{array}$ & $\begin{array}{c}\text { Third } \\
\text { (February) }\end{array}$ \\
\hline Aa \% of original sample & 34.17 & 39.38 & 48.77 \\
\hline As \% of last tracked sample & & 16.76 & 24.89 \\
\hline As \% of first tracking tracked sample & & & 32.55 \\
\hline Total sample & 5007 & 5007 & 5007 \\
\hline Total sample tracked last time & & 3296 & 3035 \\
\hline Total sample tracked current time & 3296 & 3035 & 2565 \\
\hline
\end{tabular}

The industry and city distributions for the total lost sample from the third tracking (February 2009) are reported (Table 12.5). All the cities had lost more than 30 per cent of the original sample in the third tracking. Among the total lost sample, cities that had lost more than 50 per cent of the sample were Guangzhou, Dongguan, Nanjing, Hangzhou, Ningbo and Wuhan. Although most of these cities are in the coastal region, where export industries are concentrated, except for Wuhan, the cities with the highest and third-highest export concentration levels - Shenzhen and Shanghai - are not among this list. It is also interesting to see that Nanjing and Ningbo have extremely high rates of attrition-more than 10 percentage points higher than Dongguan, whose export concentration exceeds the former two cities by a large margin. 


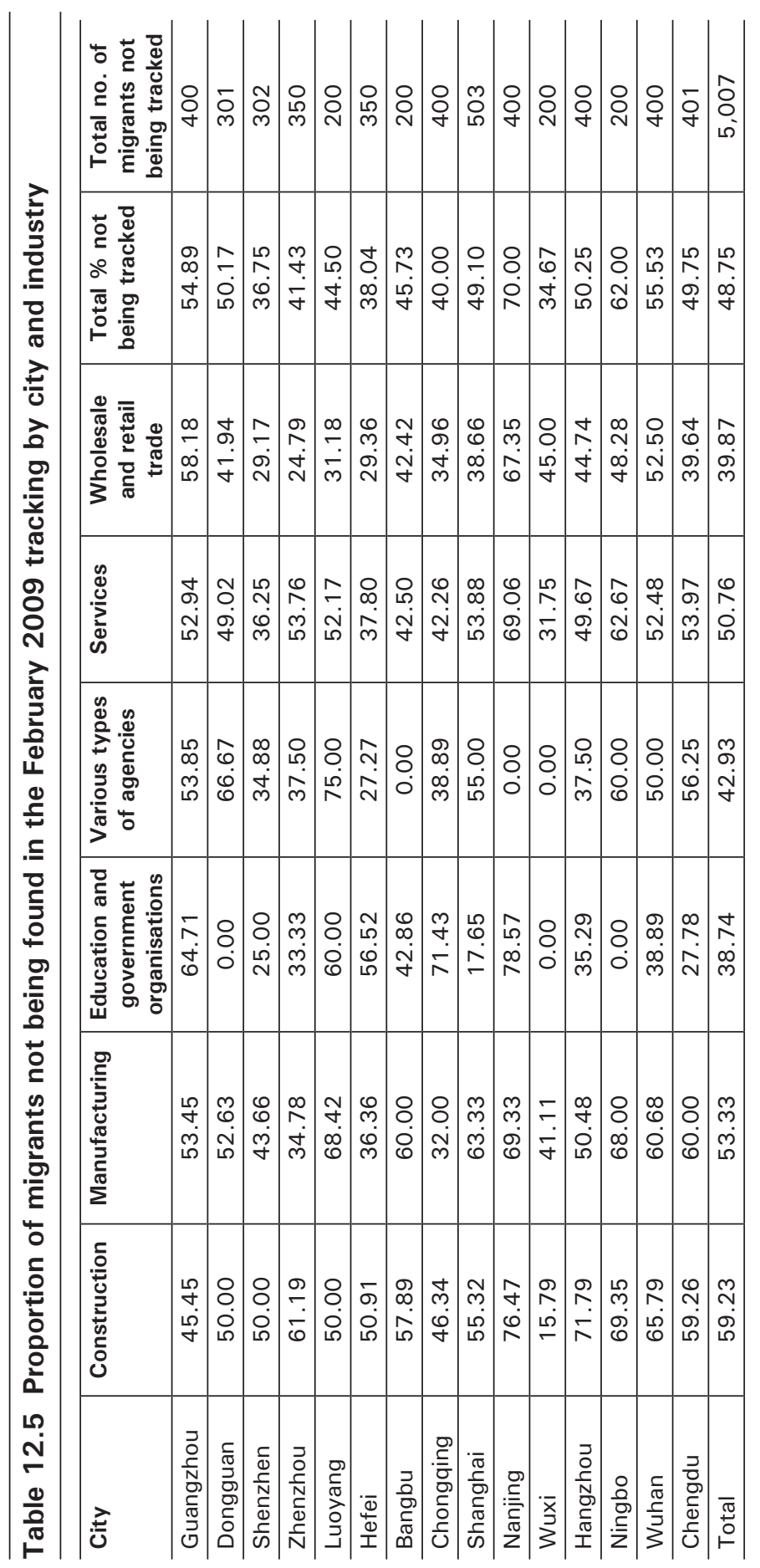


Among the six industry groups, construction, manufacturing and services lost more than 50 per cent of the original sample, of which the impact on manufacturing industries can be tied directly to the global financial crisis due to its export intensity, whereas this might not be the case for the construction and service industries. The high attrition rate across the board for different cities and the fact that the non-tradable sectors (construction and services) are hit equally hard are suggestive of the fact that the impact on migrant employment comes not only from the global financial crisis but is a combined effect of domestic macroeconomic policies and external shocks.

\section{Who has borne the brunt of the economic downturn?}

Another interesting issue to examine is who, among the rural-urban migrants, has been affected the most by the economic downturn. In this section, we utilise our 2008 survey data combined with the tracking records to investigate this issue.

In the 2008 survey, we collected a rich set of information about the households and individual migrants. Using these data, we are able to identify the individual and household characteristics of the group, which we are unable to record in each of the three trackings. We estimate the linear-probability model of whether a household is tracked in each of the three trackings. The independent variables include household and household head characteristic variables, such as household size, the age of the household head, his/her gender, marital status, years of schooling, year since migration, number of cities he/she has worked in since first migrating, the household head's 2008 job descriptions (workplace size, whether the workplace was in the manufacturing or construction sector and whether the individual was self-employed) and a subjective variable indicating whether, if the policy allowed, the household would like to stay in the city forever. In addition, we include a group of city-level dummy variables. The estimated results are reported (Table 12.6). 
Table 12.6 Regression results on probability of being tracked in each of the three trackings

\begin{tabular}{|c|c|c|c|}
\hline & $\begin{array}{c}\text { Being } \\
\text { tracked } \\
\text { (Oct. 2008) }\end{array}$ & $\begin{array}{c}\text { Being } \\
\text { tracked ( } \\
\text { Oct. 2008) }\end{array}$ & $\begin{array}{c}\text { Being } \\
\text { tracked } \\
\text { (Feb. 2009) } \\
\end{array}$ \\
\hline \multirow[t]{2}{*}{ Age } & 0.019 & 0.020 & 0.015 \\
\hline & {$[0.005]^{* * *}$} & {$[0.005]^{* * *}$} & {$[0.005]^{* * *}$} \\
\hline \multirow[t]{2}{*}{$\mathrm{Age}^{2} / 100$} & -0.024 & -0.026 & -0.022 \\
\hline & {$[0.006]^{* * *}$} & {$[0.006]^{* * *}$} & {$[0.007]^{* * *}$} \\
\hline \multirow[t]{2}{*}{ Dummy for males } & 0.022 & 0.011 & 0.038 \\
\hline & [0.015] & [0.015] & {$[0.016]^{* *}$} \\
\hline \multirow[t]{2}{*}{ Dummy for married } & 0.047 & 0.037 & 0.036 \\
\hline & {$[0.022]^{* *}$} & {$[0.022]^{*}$} & [0.023] \\
\hline \multirow[t]{2}{*}{ \# of household member } & 0.019 & 0.029 & 0.048 \\
\hline & {$[0.009]^{* *}$} & {$[0.009]^{* * *}$} & {$[0.009]^{* * *}$} \\
\hline \multirow[t]{2}{*}{ Years of schooling } & 0.012 & 0.016 & 0.015 \\
\hline & {$[0.003]^{* * *}$} & {$[0.003] * * *$} & {$[0.003]^{* * *}$} \\
\hline \multirow[t]{2}{*}{ Year since first migration } & 0.003 & 0.005 & 0.007 \\
\hline & {$[0.001]^{* *}$} & {$[0.001]^{* * *}$} & {$[0.001]^{* * *}$} \\
\hline \multirow[t]{2}{*}{ \# of cities worked since first migrated } & -0.009 & -0.007 & -0.008 \\
\hline & {$[0.003]^{* * *}$} & {$[0.003]^{* *}$} & {$[0.003]^{* *}$} \\
\hline \multirow[t]{2}{*}{ If allowed will stay in city forever } & 0.038 & 0.032 & 0.035 \\
\hline & {$[0.014]^{* * *}$} & {$[0.014]^{* *}$} & {$[0.015]^{* *}$} \\
\hline \multirow[t]{2}{*}{ Working in Manufacturing industry } & -0.063 & -0.057 & -0.065 \\
\hline & {$[0.020]^{* * *}$} & {$[0.020]^{* * *}$} & {$[0.021]^{* * *}$} \\
\hline \multirow[t]{2}{*}{ Working in construction industry } & -0.103 & -0.096 & -0.145 \\
\hline & {$[0.025]^{* * *}$} & {$[0.026]^{* * *}$} & {$[0.026]^{* * *}$} \\
\hline \multirow[t]{2}{*}{ Self-employed } & 0.058 & 0.031 & 0.014 \\
\hline & [0.041] & [0.041] & {$[0.042]$} \\
\hline \multirow[t]{2}{*}{ Dongguan } & -0.111 & 0.061 & 0.048 \\
\hline & {$[0.036]^{* * *}$} & {$[0.037]^{*}$} & {$[0.038]$} \\
\hline \multirow[t]{2}{*}{ Shenzhen } & 0.064 & 0.260 & 0.210 \\
\hline & {$[0.036]^{*}$} & {$[0.037]^{* * *}$} & {$[0.037]^{* * *}$} \\
\hline \multirow[t]{2}{*}{ Zhenzhou } & 0.230 & 0.275 & 0.131 \\
\hline & {$[0.035]^{* * *}$} & {$[0.036]^{* * *}$} & {$[0.037]^{* * *}$} \\
\hline \multirow[t]{2}{*}{ Luoyang } & 0.108 & 0.185 & 0.102 \\
\hline & {$[0.041]^{* * *}$} & {$[0.042]^{* * *}$} & {$[0.043]^{* *}$} \\
\hline \multirow[t]{2}{*}{ Hefei } & 0.103 & 0.301 & 0.150 \\
\hline & {$[0.035]^{* * *}$} & {$[0.036]^{* * *}$} & {$[0.037]^{* * *}$} \\
\hline \multirow[t]{2}{*}{ Bangbu } & 0.186 & 0.272 & 0.048 \\
\hline & {$[0.042]^{* * *}$} & {$[0.042]^{* * *}$} & [0.043] \\
\hline \multirow[t]{2}{*}{ Chongqing } & 0.212 & 0.234 & 0.128 \\
\hline & {$[0.033]^{* * *}$} & {$[0.034]^{* * *}$} & {$[0.035]^{* * *}$} \\
\hline
\end{tabular}




\begin{tabular}{l|c|c|c}
\hline & $\begin{array}{c}\text { Being } \\
\text { tracked } \\
\text { (Oct. 2008) }\end{array}$ & $\begin{array}{c}\text { Being } \\
\text { tracked ( } \\
\text { Oct. 2008) }\end{array}$ & $\begin{array}{c}\text { Being } \\
\text { tracked } \\
\text { (Feb. 2009) }\end{array}$ \\
\hline Shanghai & 0.097 & 0.213 & 0.036 \\
\hline Nanjing & {$[0.032]^{* * *}$} & {$[0.032]^{* * *}$} & {$[0.033]$} \\
\hline Wuxi & 0.095 & 0.158 & -0.136 \\
\hline Hangzhou & {$[0.033]^{* * *}$} & {$[0.034]^{* * *}$} & {$[0.035]^{* *}$} \\
\hline Ningbo & 0.062 & 0.239 & 0.220 \\
\hline Wuhan & {$[0.041]$} & {$[0.042]^{* * *}$} & {$[0.043]^{* *}$} \\
\hline & 0.085 & 0.147 & 0.048 \\
\hline Chengdu & {$[0.033]^{* *}$} & {$[0.034]^{* * *}$} & {$[0.035]$} \\
\hline & 0.118 & 0.021 & -0.039 \\
\hline Firm size & {$[0.041]^{* * *}$} & {$[0.042]$} & {$[0.043]$} \\
\hline Observations & 0.036 & 0.114 & -0.027 \\
\hline R-squared & {$[0.034]$} & {$[0.034]^{* * *}$} & {$[0.035]$} \\
\hline Standard & 0.157 & 0.285 & 0.038 \\
\hline$[0.034]^{* *}$ & {$[0.034]^{* *}$} & {$[0.035]$} \\
\hline Yes & $Y$ Yes & Yes \\
\hline & 4897 & 4897 & 4897 \\
\hline & 0.07 & 0.09 & 0.09 \\
\hline
\end{tabular}

Standard errors in brackets

* significant at $10 \% ; * *$ significant at $5 \% ; * *$ significant at $1 \%$

We find that the results are largely consistent across the equations for three different sets of tracking data. In general, age has a positive effect on being tracked, but it reaches the peak about thirty-five to forty. By age fifty-five, the probability of being tracked reduces to the same level as that for those aged sixteen (Appendix 12.1). Males, married individuals and migrants who have other family members living in the same cities with them are more likely to be tracked. In addition, those who have a higher education level and longer migration experience are more likely to be tracked, while those who often change places and those who do not want to stay in city forever, even if allowed to, are less likely to be tracked. These results are quite intuitive. If we believe that attrition, to a certain extent, indicates the adverse employment impact of the economic downturn, the above results can be read as showing that individuals who are single, not in the primary working-age group, are less educated and have less migration experience are more likely to be adversely affected by the economic downturn. These findings are largely consistent with the literature on unemployment in most countries (for example, Devine and Kiefer 1991; Svejnar 1999). 
With respect to employment, it seems that those who worked in the manufacturing and construction industries in 2008 were more likely to have left their previous job than those who worked in tertiary industries. The effect is much stronger for the construction industry than for the manufacturing industry, especially in the third tracking, where the effect on a construction job is twice as high as that on a manufacturing job. Working in the construction sector in 2008 increases the probability of having left that job by February 2009 by 15 per cent, while the probability of leaving a manufacturing job is 7 per cent. Neither self-employment nor firm size has an effect on leaving the job.

Conditional on all the above variables, relative to Guangzhou, almost all cities have a higher probability of being tracked, except Dongguan in October 2008. By the second and third tracking, Dongguan has a higher probability of being tracked, while the probability for Nanjing has dropped dramatically to below Guangzhou's level.

\section{Conclusion}

In this chapter, we use a unique set of data from the RUMiCI project to investigate the employment impact of the economic downturn on ruralurban migrants. We find that, on average, the total effect of the economic downturn has adversely affected 13-19 per cent of jobs for rural-urban migrants. These estimates are higher than those in the existing literature using data from migrant sending regions, which estimate that about 10-15 per cent of migrants are affected by the economic downturn.

We also find that the group of migrants whose jobs are most likely to be affected by the economic downturn is the one comprising those who would normally be affected in any economy. These are the people who are less educated, single, not in the primary age group and have less migration experience.

Our analysis indicates that job loss is not confined to the exportconcentrated coastal regions. The majority of cities in our sample have had significant jobs losses. In fact, two of the top export-concentrated cities - Shenzhen and Shanghai - have had a low level of job loss relative to their interior counterparts.

We also find that job loss is not confined to export-manufacturing industries. Indeed, the non-traded goods sectors-construction, retail and wholesale - are where most job losses occur. 
We interpret the widespread nature of this job loss, and the heavy incidence of job losses outside the export industries, to indicate that job losses in China are primarily a response to factors other than the decline in export markets. In particular, tight monetary policy in the past few years was important at the start of the current downturn and the introduction of the new Labour Contract Law could also be responsible. Of course, as the economy responds to the global financial crisis, this pattern of job loss could change and the loss of jobs in the export sector, at least in relative terms, could become more important.

\section{References}

Batson, A. 2008, 'China aids home buyers to curb impact of slump', Wall Street Journal, 24 October 2008.

Cooney, S., Biddulph, S., Kungang, L. and Zhu, Y. 2007, 'China's new Labour Contract Law: responding to the growing complexity of labour relations in the PRC', UNSW Law Journal, vol. 30, no. 3, pp. 788-803.

Devine, T. J. and Kiefer, N. M. 1991, Empirical Labor Economics: The search approach, Oxford University Press, Oxford.

Olsen, R. J. 2005, 'The problem of respondent attrition: survey methodology is key', Monthly Labor Review, February 2005, pp. 63-70, $<$ http://www.bls.gov/opub/mlr/2005/02/art9full.pdf>

Svejnar, J. 1999, 'Labor markets in the transitional Central and Eastern European economies', in O. Ashenfelter and D. Card (eds), Handbook for Labor Economics. Volume 3B, Elsevier, North-Holland, pp. 1809-2858.

Wang, H., Appelbaum, R. P., Degiuli, F. and Lichtenstein, N. 2009, 'China's new Labour Contract Law: is China moving towards increased power for workers?', Third World Quarterly, vol. 30, no. 3, pp. 485-501.

Watson, N. and Wooden, M. 2004, Assessing the quality of the HILDSA survey wave 2 data, HILDA Project Technical Paper Series, no. 5/04, Melbourne University, Melbourne.

Wong, E. 2008, 'Factories shut, China workers are suffering', New York Times, 14 November 2008.

Zhao, L. and Lim, T. S. 2008, China's new Labour Contract Law: belated convent to better protection of workers, EAI Background Brief, no. 378, 10 April 2008, East Asian Institute, National University of Singapore. 


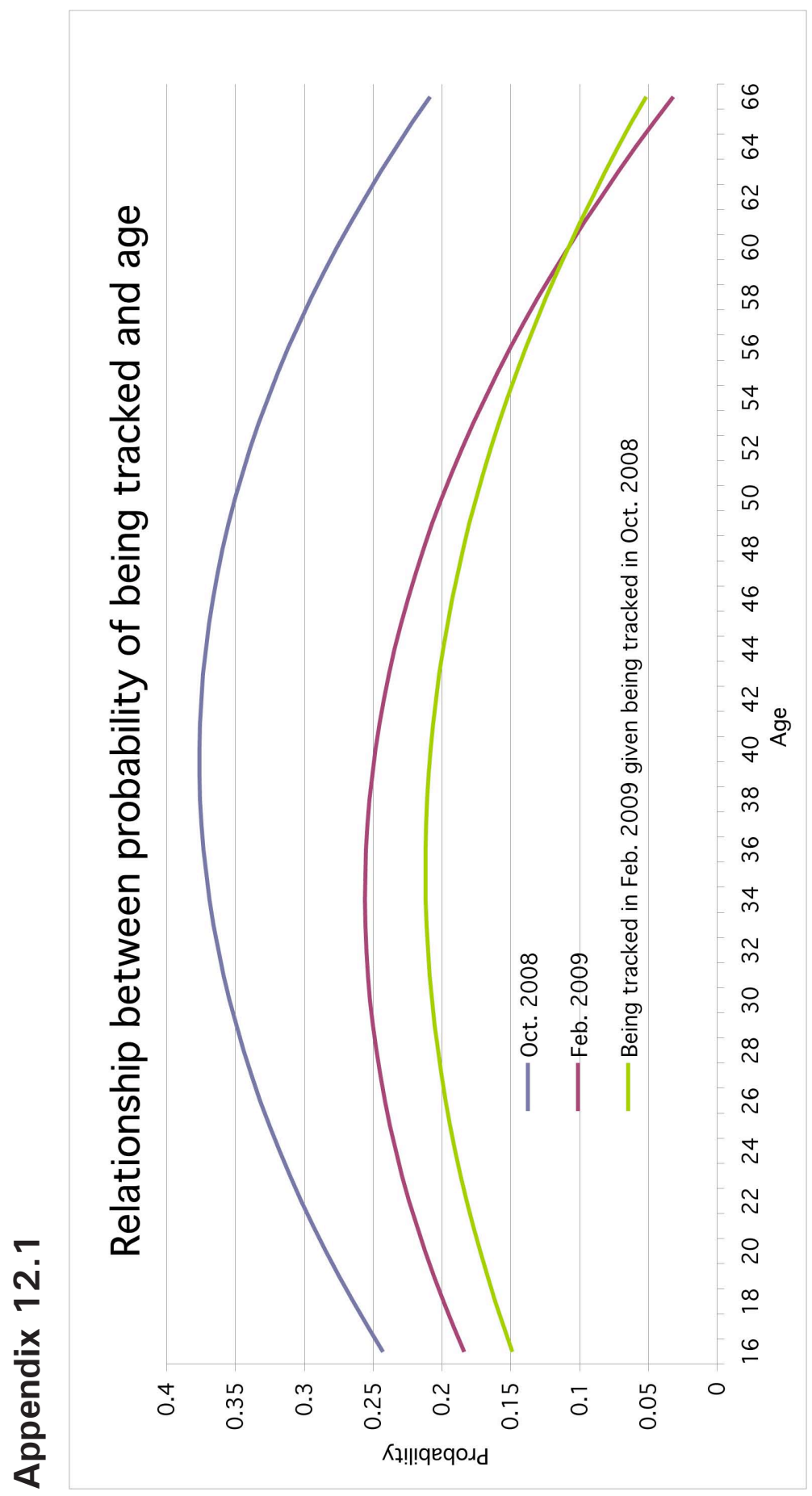




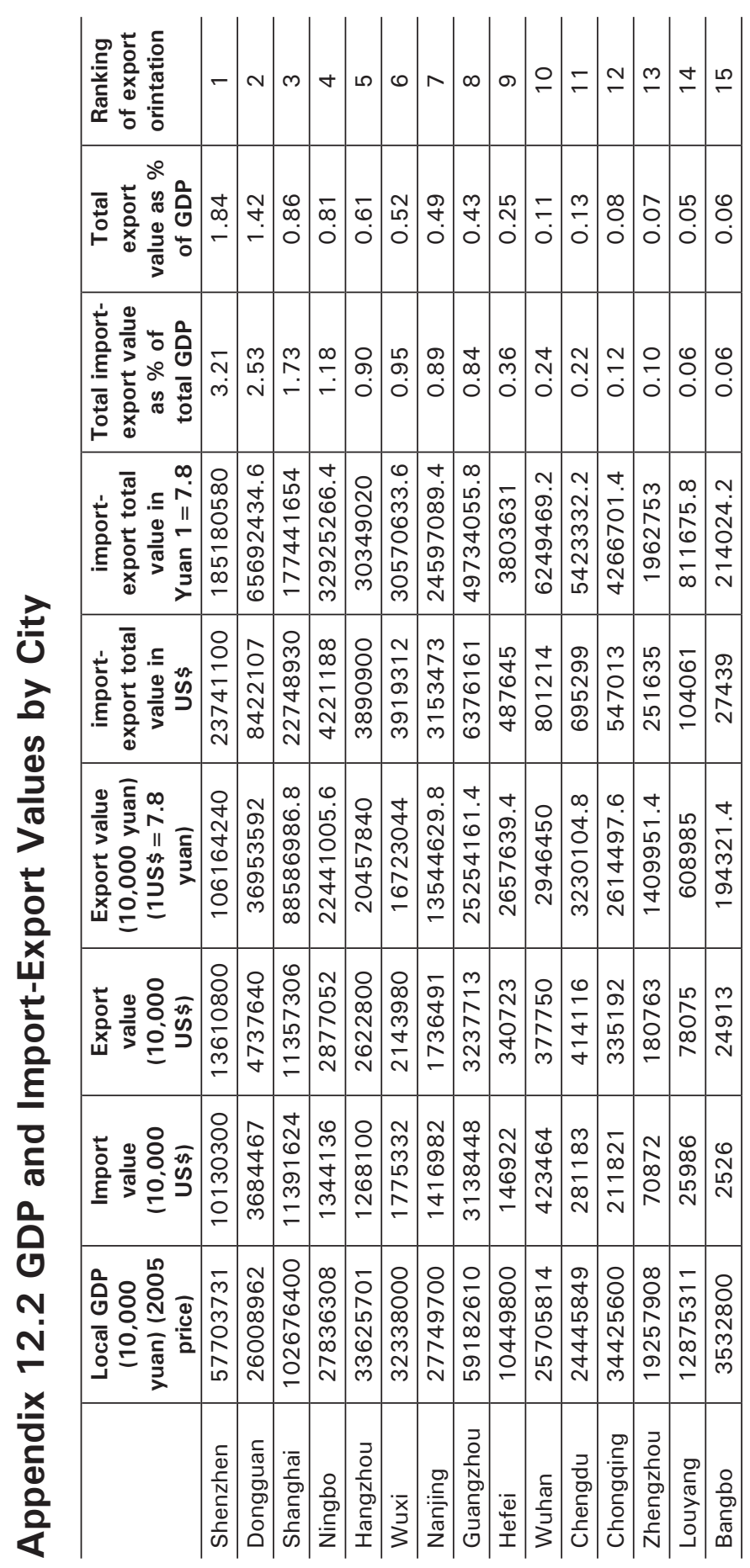




\section{Endnotes}

1. These data were released by Xiwen Chen, the Director of the Chinese Communist Party's Office on Rural Policy, during a news conference in Beijing on 2 February 2009.

2. The 15 cities are Shanghai, Guangzhou, Shenzhen, Dongguan, Nanjing, Wuxi, Hangzhou, Ningbo, Wuhan, Chongqing, Chengdu, Hefei, Bangbu, Luoyang and Zhengzhou.

3. The RUMiCI project is funded by the Australian Research Council, the Australian Agency for International Development (AusAID) and the Ford Foundation.

4. For detailed information regarding sampling methodology, see $<$ http://rumici.anu.edu.au/ $>$

5. The 2009 Chinese New Year was 26 January. Normally, migrant workers return to their rural home village for Chinese New Year and come back to the city about 15-20 days afterwards. Our last tracking, therefore, was conducted after 15 February 2009, when the majority of migrant workers had come back to cities.

6. The total number of blocks in the census in 2007 and the number of blocks in the re-census in 2009 are listed in Appendix 12.1. 